\title{
Political Godfatherism and Governance in a Developing Democracy: Insight from Nigeria
}

\author{
Joseph Okwesili Nkwede, Ph.D
}

Department of Political Science Ebonyi State University, Abakaliki. Nigeria. Email: senatorlife2011@yahoo.com.

Ibeogu Aloysius S.

Department of Public Administration Ebonyi State Uirversity, Abakaliki. Nigeria

Email: bogito_son@yahoo.com

Nwankwo Oliver U.

Department of Political Science Ebonyi State University, Abakaliki. Nigeria

\section{Doi:10.5901/ajis.2014.v3n4p137}

\section{Abstract}

This paper focuses on political godfatherism and governance in a developing Democracy with special attention to Nigeria. Its staggering posture in Nigerian politics gave rise to the evaluation of the concept and its impact on the politics of the country. The cardinal objective is to investigate whether political godfathersim affect good governance in Nigeria. The study employed descriptive and content analytical method in the analysis of data. The findings of this study indicated that godfatherism has threatened the country's nascent democracy. It is the position of this study among other things that competitions among godfathers to control state powers and resources through their favoured godsons have denied the electorates the right to elect their preferred candidates, thereby rendering elections ineffective and inconsequential. Besides, the fierce struggle for state power has also resulted in some of the worst electoral violence in the country, in almost all the elections that have been conducted in Nigeria since the inception of the fourth (4th) Republic, 1999 - till date, that godfatherism as practiced in Nigerian polity is a potential threat to the sustenance of democracy. This study therefore recommended that to ensure a government and democratic rule that will bring about societal development and transformation, there should be independent choice of candidates, free and fair election, financial independence of candidates, polity devoid of financial and material inducement of electorates, attitudinal change and positive perception among the team players in Nigerian politics.

Keywords: Politics, godfatherism, threat, developing democracy, state power, electorates, governance, electoral violence and godson.

\section{Introduction}

The history of political godfatherism is traceable to the colonial epoch through independence era, military interregnum and towards the restoration of democracy in Nigeria in what came to be known as the fourth Republic in 1999 following the terminus of military junta. The staggering posture of godfatherism in Nigerian democratic experiment leaves much to be desired. This stems from the fact that since the adumbration of this nascent democracy on the 29th May, 1999, Nigerians have witnessed uncontrollable political insecurity, which has threatened participatory democracy, peace, political security and the consolidation of democracy as a result of the activities of political godfathers (Ajadike 2010).

Essentially, the politics of godfatherism in Nigeria has became more visible and widespread like harmatan fire as events unfolded itself in the recent elections conducted variously in 1999, 2003, 2007, and 2011 in Nigeria. With the expansion of the activities of godfathers and its eldorado in the 21st century Nigeria, coupled with the godson clientelism, there was greater commitment and manifestations of discontentment in the developing democracy of Nigeria in the areas of political security and participation. It should also be mentioned that the fourth Republic Political godfathers are essentially predatory in their motivation to influence electoral politics and subsequent elections in Nigeria (Gambo, 2007) Unfortunately, the down of the new millennium witnessed various manifestations of discontentment demonstrated on a patro - client relationship with increasing frequency and intensity bordering on participation, political security, and peace as it torpedoes the consolidation of democratic governance and dividends in the country. Aiyamenkhue (2010:10) noted that: 
faith in our democratic government and an increasing frustration at government, and more also, an increasing frustration at the irrelevance of individual's vote in our political process. All these crises are caused by the unholy alliance of godfatherism.

As a corollary of the above, the desire to venture into the burgeoning challenges became sacrosanct. The rationale for this paper therefore, is to x-ray the activities of godfatherism in the governance of Nigeria in selected states with a view to suggesting ways of eliminating the menace in the body politics of the country.

\section{Statement of the Problem}

There is hardly any issue or social phenomenon that has attracted and continues to attract scholarly attention as political godfather and godson in Nigeria. Political godfather and governance are related but contradictory phenomenon in which a lot of intellectual energy has been directed towards understanding their fundamental nature, character, causes and effects or impact on Nigerian democracy.

Attempts by scholars to define, categorize, qualify or quantify political godfather in Nigeria have led to a huge body of literature consistently churned out, in attempt to explain its causal factors, processes and constraints. Over the past fourteen years, therefore Nigeria's grave political development crisis have generated a growing body of analyses and prescriptions on what has gone wrong and what should be done (Gideons, 2010). The dominant strands of analytical expositions have appeared prominent in the political and intellectual circle, giving rise to diametrically oppressed interrogation of the injection of godfatherism in Nigeria's body Politics.

Experience has, however, shown that the application of this concept has mostly resulted to democratic failures and disasters. From denial of electing credible candidates to imposition of mediocrity into political and appointive positions, and the whole experience has been that of pains, misery, penury, squalor and damnation arising from poor performance and poor service delivery among godsons.

Again, the whole scenario has been the promotion of political follow-follow mentality and the empowerment of disempowerment. The point that needs to be reinstated here above all is that, it is impossible to understand the character of political godfatherism in the past and its contemporary forms in the Nigeria's fourth republic.

It is against this backdrop that the research questions below become sacrosanct;

i. What are the factors affecting good governance in Nigeria?

ii. Has political godfatherism lead to poor delivery of democratic dividends in Nigeria?

\section{Objectives of the Study}

i. To determine whether political godfatherism affects good governance in some states in Nigeria.

ii. To ascertain whether political godfatherism has lead to poor delivery of democratic dividends in Nigeria.

\section{Hypotheses}

i. Ho1: Political godfatherism has affected good governancein Nigeria.

$\mathrm{Ho}^{2}$ : Political godfatherism has not affected good governance in Nigeria.

ii. Ho1: Political godfatherism has lead to poor delivery of democratic dividends in Nigeria

$\mathrm{Ho}^{2}$ : Political godfatherism has not lead to poor delivery of democratic dividends in Nigeria.

\section{Literature Review}

Several attempts have been made by scholars to pin down the etymological meaning and nature of political godfatherism. Apparently, some scholars have argued that political godfatherism in the developing countries is part of institutional building and that it is still part of development while at the same time its appeals constitute the heaviest milestones of any country (Ome,2004).

To some, political godfatherism connotes the invasion of the political candidates by discarnate powerful sponsor, tending to complete possession for the purpose of selfish gratification (Mbamara, 2004, Bassey and Enetak, 2008). For them, the godfather is the political slave merchant while the godson is the political slave or slave boy or political article for sale. The godson is purchased with big sum of money under a democratic oath. Their aims and objectives include appointments, stealing, robbery and looting of government treasury. The decision making 
appointments and contract awards is usually manipulated by the godfather. In the words of Ajayi (2014), Chukwuemeka, Oji and Chukwurah (2013), godfatherism is a kind of;

Politics whereby an influential person in a popular or ruling party will assist someone usually a lackey, i.e godson to emerge as the governorship candidate of a party at all cost and either by hook or crook, he will help him to emerge victorous in the state governorship election irrespective of whether he is a popular candidate or not.

Intuitively, political godfatherism represents a self-seeking individual out there to use the government for his own purposes. The cost of this incidence is enormous to the state as what usually obtains is that when the incumbent godson is at pains to satisfy the whims and caprices of the godfather among other competing demands on the scarce resources of the government, the interest of the larger number is savagely undermined. This according to Joseph (1999:54) has left democracy in Nigeria to assume the form of prebendalism.

Contemporaneously, governance is another contested concept in this discourse. However, there is a plethora of views by scholars and development institutions on what the concept connotes. The World Bank (1991) views governance as "The manner in which power is exercised in the management of a country's economic and social resources for development". Governance primarily demands that state operators deploy state resources in a manner that ensures material advancement for the people. Egwu (2005) opined that one of the areas rocking the post-colonial African state is the prevalence of unaccountable government. Hyden and Bratton (1991) refer the governance as "The conscious management of regime structure with a view to enhancing the legitimacy of the public sphere".

The United Nation Development Programme (1997) conceives governance as:

\begin{abstract}
...the totality of the exercise of authority in the management of a country's affairs comprising complex mechanisms, processes and institutions through which citizens and groups articulate their interests, exercise their legal rights and mediate their differences.
\end{abstract}

In spite of the divergence of views on governance, they emphasize public accountability and rule of law as the brainbox of good governance. From the above, it can be stated that political godfatherism is at variance with good governance.

From this standpoint, it can safely be argued that political gofatherism is an invention designed and tailored to bring political underdevelopment in the third world countries. It entails a programme of systematic tango in a political environment or institutions, with the primary aim of making the majority that constitute the electorates perpetually underdogs and subterfuge of the political process.

\title{
6. Theoretical Paradigm
}

It has become a universal phenomenon in social sciences for facts to be investigated or examined precisely within a paradigm, rather than in an isolated manner. For Goode and Hatt (1952), theoretical orientation functions mainly by bridging the range of facts that are to be investigated. Ipso facto, in an empirical theoretical base, it is necessary to develop a sound theory, which is capable of explaining the wise concepts and relationships in the study. The essentiality of theoretical paradigm in a study is also pigeon-hold in the fact that social science research is theory based and its operations are guided by relevant principles of human behaviour (Goode and Hatt, 1952).

Consequently, this study is anchored on elite theory. The major assumptions of elite theory is that in every society there is, and must be a minority which rules over the rest of society, and this minority forms the political class or governing elite composed of those who occupy the posts of political command and more regularly those who can directly influence political decision. They undergo changes in its membership over a period of time, ordinarily by the recruitment of new individual members from the lower strata of the society, sometimes by the incorporation of new social groups, and occasionally by the complete replacement of the established elite by a counter-elite. Writers like Saint Simon, Hippolyte, Ludwis, Karl Marx, Vilfred Pareto Gaetano opined that in every branch of human activity each individual is given an index which stands as a sign of his capacity, very much the way grades are given in the various subjects in examinations in school (Suenu, 2004, Nkwede, 2014). According to Suenu who is the leading proponent of this elite paradigm, an elitist correlation to the understanding of godfatherism is very apt. He sees godfatherism as being synonymous with the elites. For him, elites in the political spheres are known in Nigerian context as godfathers. They are the ones who govern, and are known as the kingmakers, the notables and often seen as strongmen who control politics in their different domains. Apparently, in a political environment where godfatherism is in vogue, individuals are colonized by the godfathers. In order words, godfathers rule by proxies.

The relevance of this theory to the current study cannot be overemphasized. This is because of its interconnectivity 
to the explanation of political godfatherism and governance.

\section{Methodology}

A self-administered questionnaire was employed for gathering data in this study. The study areas were Anambra, Enugu, Ebonyi and Oyo Sates respectively. The choice of these States were made as a corollary of incidence of godfatherism politics evidenced in those areas. The questionnaire administered was carefully designed in dichotomous and multiple choice approach via; agree, strongly agree, undicided, disagree and strongly disagree.

The questionnaire's validity and reliability were determined through content validity and its reliability determined through a pilot survey of Anambra, Enugu, Ebonyi, and Oyo State. Content and percentage analysis were used in analyzing the data collected.

\section{Manifestations of Godfatherism in Nigeria's Democracry Since 1998 - 2013.}

\subsection{Pre-Transition Period (1998-1999)}

Prior to the transition to a democratically elected government in 1999, there was an annulment of the June 12, 1993 presidential election, supposedly won by Chief M.K.O Abiola, by General Ibrahim Babangida. This gave room for the appointment of Chief Ernest Shonekon as head of interim national government, which later paved way for General Sani Abacha to assume duty as the Head of State on 18 th November, 1993 through a palace coup. Five years later, General Sani Abacha died on $8^{\text {th }}$ June1998, then the idea of godfatherism started manifesting as Lieutenant General Jeremiah Useni, Chief of General Staff (next to Abacha) was supposed to take over, but Rtd General Ibrahim Badamosi Babangida, preferred Major General Abdulsalami Abubakar, Chief of Defence staff, Lagos, and a junior army officer to Lt Gen Jeremiah Useni. Major General Abdulsalami Abubakar was moved from Lagos to Abuja, promoted to the rank of a General (became a senior to General J. Useni) and made him the head of state on $9^{\text {th }}$ June 1998. Lieutenant General Jeremiah Useni immediately resigned from the military, as he could not watch a junior army officer become the head of state, when he should have been made the head of state and Commander -in - chief of the Armed Forces. Since that power play, it has never augured well with General Jeremiah Useni and the likes of general Ibrahim Babangida and General Abdulsalami Abubakar (Ibeogu, 2013). Shortly after General Abubakar assumed duty as the head of state and Commander-in-Chief of Armed Forces, he announced the programme to the transition to civil rule, which include the release of political and military detainees like Lieutenant General Oladipo Diya (former Chief of General Staff), General Olusegun Obasanjo (former Head of State), Senator Polycarp Nwite etc. Having released the programme to the transition to civil rule, General Yakubu Gowon, in a close chat with General Olusegun Obasanjo, having been released from the prison, disclosed his intention of vying for the office of the presidency, General Obasanjo in a reply, asked General Yakubu Gowon what he forgot in the presidential villa which he failed to collect during his nine (9) years of military rule, 1966-1975, (Odey, 2003). Shortly after the chat, General Ibrahim Babangida nominated Rtd General Olusegun Obasanjo as the PDP flag bearer for 1999 Presidential election having annulled the fairest election that was acclaimed to have won by Chief MKO Abiola who hails from the same state (Ogun) with General Obasanjo; all were to pacify and placate the Yoruba's for that criminal act, but what baffles Nigerians was that General Olusegun Obasanjo quickly accepted, forgetting the question he asked general Gowon few weeks back (Ibeogu, 2013). This nomination by General Babangida for General Obasanjo becoming PDP flag bearer for the 1999 Presidential election and subsequent emerging as the president could be one of the factors that incapacitated General Obasanjo from implementing the recommendation of Justice Chukwudifu Oputa panel in 2002 that indicted General Ibrahim Babangida for high level fraud and corruption in Nigeria (1985 - 1993) as a military President (Ibeogu, 2013).

\subsection{The Anambra State Experience (1999-2006)}

Anambra state has in the recent time been faced with the problem of godfatherism virtually in all elective positions, with that of gubernatorial position taken at different dimension. From 1999-2003, the battle was between Emeka Offor and Dr. Chinweoke Mbadinuju (godfather and godson). Dr. Mbadinuju (godson) refused to dance to the tune of the godfather. This led to Dr. Mbadinuju losing the gubernatorial ticket for Peoples Democratic Party (PDP) and his difficulty returning to Anambra government house in 2003. The political bickering and acrimony raised by these two actors are yet to settle when two others emerged, Chief Chris Uba and Dr. Chris Ngige. Chief Chris Uba was the godfather responsible for the 
installation of Dr. Chris Ngige as the governor of Anambra state in 2003. Dr. Chris Ngige promised Chief Chris Uba of total loyalty if made the governor. Chief Uba ensures that Dr. Ngige became the governor by bearing the election expenses. After the election, Dr. Ngige refused to pay back his godfather the necessary commission and patronage. Since then peace never returned to the seat of power in Anambra, Dr. Ngige was abducted and also purportedly resigned. However, there was an electoral battle at the court, until the court of appeal declared his victory as a stolen mandate and ordered that the All Progressive Grand Alliance (APGA) candidate, Dr. Peter Obi be sworn in on $26^{\text {th }}$ March 2006 as governor, which was the beginning of scattered elections in Nigeria in this political dispensation.

\subsection{The Enugu State Experience (1999 - 2011)}

From 1999 - 2007, when Dr. Chimaroke Nnamani became the governor of Enugu state, there was an unending rift between him (Governor) and his political godfather, Chief Jim Nwobodo. Dr. Nnamani was unable to settle Chief Jim Nwobodo to his satisfaction, so the two fell apart. By 2007 - 2011, it was the turn of Barrister Sullivan Chime, as Dr. Chimaroke Nnamani did all he could to install Chime. As soon as Barrister Chime emerged as governor, Dr. Nnamani sent a long list of political appointees to Chime, and also demanded to have about seventy percent (70\%) control of the spoils of office in Enugu Government House, this did not go down well with Barrister Chime, so they fell headlong. Ndubuisi (2011) as quoted in Chukwuma (2012) argued that the high level of political instability in Enugu state today is as a result of the activities of godfathers. He also lamented that Enugu state has lost huge sums of money that would have been used to develop the state to settle godfathers.

\subsection{The Ebonyi State, Abakaliki L.G.A (2007 - 2013) Experience}

The immediate past chairman of Abakaliki Local Government Area, Honourable Emmanuel Uguru was elected council chairman in 2003. His tenure expired in 2005, he was reappointed as caretaker committee chairman in 2005 and transition committee chairman in 2005 and 2006, respectively. However, when on assumption of office by Chief Martin Elechi as the governor in May 29th 2007, there was to be a council election in October 2007 to elect new chairmen, but the Ebonyi State House of Assembly amendment of Local Government Act No. 4 disqualified him, as the provision of that law stated that any council boss who have served two tenures is not qualified to contest. Hon. Emmanuel Uguru who has served three tenures, (2003 - 2005, 2005 - 2006, 2006 - 2007) bowed out and brought Mr Mathew Uguru who was the chairman of Enyi Edda development centre and who never indicated interest to contest the council pools and installed him as the chairman of Abakaliki Local Government Area. As usual for godfathers in Nigeria, on assumption of office by Mr. Mathew Uguru, Hon. Emmanuel Uguru made a long list of requests and wanted to have substantial control of what happens in Abakaliki Local Government Area. This did not go down well with the council chairman, so two of them fell headlong the Hon. Emma Uguru who is known as pillar and father of PDP in Abakaliki Local Government Area resigned his membership of PDP and decamped to ANPP to look for greener pasture. Under the ANPP he contested for the Abakaliki / Izzi Federal constituency and lost. Since 2011 that he lost the Federal constituency election, he has not been given the deserved attention and recognition he use to enjoy in Abakaliki Local Government Area and Ebonyi state defecting to ANPP in 2011. Worst still is that his godson (Mathew Uguru, and political enemies) have done anything humanly possible to frustrate his personality in Abakaliki Local Government Area and Ebonyi state.

\subsection{The Oyo State Experience (2003 - 2007)}

In Oyo state during the tenure of Alhaji Rashidi Ladoja, the story was the same. Alhaji Lamidi Adedibu accused his godson (Governor) of not being loyal and submissive. He was quoted to have said, "I put him there, so, if I demand money, will it be wrong? Do I need to ask for it"? (Agbase, 2003: 21). Other charges against the former governor were, that he disregarded the principle of separation of powers and the purchase of 33 graders at the sum of seven hundred million naira (N700m) only without going through tenders board in violation of section 190(2) and (3) of local government system law of 2001 (Apabiekun, 2006:18).

To that effect, the Chief Judge of the state constituted a panel to investigate the allegation leveled against the governor, the inauguration was secretly done by the Chief Judge who never made any public appearance throughout the sitting at an Ibadan high court. When the panel submitted its report, an eight pro - impeachment legislators held a session in parliament during which they adopted the report of Ayorinde's panel and passed a motion for Rashidi Ladoja's impeachment within 25 minutes. 


\section{Consequences of Godfatherism to Nigeria's Government and Democratic Rule}

Throughout the period of military rule and in the Nigeria's fourth republic (1999-2013), emergence of godfatherism posed a great threat not only to good governance but also to the socio-economic development and stability of democratic governance. Perhaps, one of the most disturbing and damaging influence of godfatherism in Nigeria's fourth republic was in domain of making nonsense of a truly free, fair and credible electoral process in which the electorates by right are expected to freely elect people of their choice into public office to represent their interests.

Indeed, the privilege of electing people of their choice into public office was denied given the situations in which godfathers foisted candidates of their preference on the generality of the people. This is to say the least very inimical to the tenets of democratic rule (Chukwumeka, 2012).

When public office holders would not be accountable to the people, who at any rate did not count in their elections into public office, invariably, the loyalty of such public office holder would be tilted towards their godfathers and this in itself negates one of the critical attributes of governance and democracy which is responsive and transparent government. This scenario is also inimical to good governance and political stability which are predicated on the rule of law, due process, accountability and transparency in the management of public business. The emergence of godfatherism has also robbed the citizens of the privilege of enjoying the dividends of democratic governance in the sense that government has became reluctant to initiate and implement policies that would advance the well being of the generality of the citizens. This was a result of the fact that godfatherism in Nigeria was basically predatory in nature. The primary motive of venturing into politics was born out of the need to acquire wealth (money) from the coffers of government to which their godsons held sways (Chukwumeka, 2012).

Therefore, the lean financial resource accruable to the state from the federation account which was meant for the improvement of living standards of the citizens was paramount interest to them. Instances where the godsons (governors, chairmen)etc refused to settle their godfathers as agreed before securing public office, hell was let loose. The experiences recorded in Abakaliki Local Government Area, Ebonyi state, between the former chairman, Hon. Emma Uguru and Mr. Mathew Uguru (incumbent), 2007 - 2011., Senator Rashidi Ladoja of Oyo state and Alhaji Lamidi Adedibu between 2003 and 2007, alhaji Olusola Saraki and Rtd Navy Commodore Mohammed Lawal between 2003 - 2007, and Chief Chris Uba and Dr. Chris Ngige between 2003 - 2006 were awful and devastating.

The end point and consequences of these (godfatherism) in our polity is that economic activities are brought to a halt, especially education sectors, health, security (political wrangling), agriculture, housing and infrastructural developments etc.

\section{Conclusion}

The political godfathers in Nigeria see governance and political power as the cheapest and surest method of amassing wealth to the detriment of the governed. Sponsoring a weak and poor candidate to win election by appointment is seen as a lucrative business whereby the sponsor will invest heavily in imposing his candidate on the people as their leader, with all intent and protégé, called chairmen, and governors. Godfatherism is a dangerous development in Nigeria politics. The electorates are impoverished the more, and the corrupt rich godfathers are corruptly enriching themselves the more. The circle is endless, as the solution to this menaces is the serious problem facing Nigeria until a morally sound, committed and patriotic leader emerge to lead the people honestly with the attribute of transparency, openness, people oriented policies and programmes, Nigeria political development will be a mirage.

\section{Recommendations}

* Less emphasis should be placed on money for those seeking political office, rather emphasis should be placed on the credibility of the candidate seeking political office;

* The law makers should enact law to prohibit godfatherism in Nigeria's politics; offenders should be barred from political activities in Nigeria;

* The existing sentiments and parochial cleavages such as ethnicity and religion should not be a pre-requisite when it comes to attracting the suitable qualified candidates for public/political offices;

* Political parties should cultivate and promote strict disciplines among members;

* No nation can progress when her laws are not applicable to all, when some persons see themselves as sacred cows and can get away with any crime committed. This is because Nigerians are not happy with the abysmal performance of a large number of governors, Legislators and Local Government Council chairmen, 
who unfortunately cannot be called to order as long as they remain in the good books of their political godfathers;

* That the legislative arm of government be made a part time affair;

* That the immunity clause as enshrined in the constitution be expunged, so that any public officer that contravenes or violates any section of the constitution should be made to face the consequences of his actions;

* That the spoils of office and material benefits to public positions should be made less attractive;

* That paper qualification and public experience in the art of governance should be emphasized at all levels of governance to discourage mediocre from mounting the saddle of leadership.

\section{References}

Agbase, D (2003). I am Ready for Uba, Tell Magazine, December, 1

Aiyaemkhue, E (2010). Godfatherism and the Compomise of internal Democracy in Nigeria Politics, Paper Presented at Catholic Youth Organization of Nigeria, Benin, $16^{\text {th }}$ October.

Ajadike, U. (2010). The politics of godfatherism in Nigeria. Journal of Policy and Development Studies, 5(2): 25-31.

Ajayi, F (2014). Nigerian Political Godfatherism in the World of Baale Molete www.nigeriaworld.com downloaded on the $7^{\text {th }}$ February.

Ake, C. (1995). Is Africa Democratizing? In Mimiko, N. O. (ed) Crisis and Contradiction in Nigeria's Democratization Programme 1986 1993. Akure Setback Printers.

Anakwenze, N. (2004). A paper presented to the convention of Anambra State Association, USA. Online.

Apabiekun F (2006). Ladoja's Political Suicide, Tell magazine, January 23.

Ayodele, J. (2007). Godfather Politics in Nigeria, Journal of Political Science 2(3); 50 - 59.

Bassey, N. and Edet, E. (2008). Godfatherism and Good Governance in Nigeria: An appraisal of Nigeria's fourth Republic. Journal of Social and Policy.

Chukwuemaka E, Oji, R. O. and Chukwurah D. J. C. (2013). Give them their Rights: A Critical Review of Godfather and Godson Politics in Nigeria. Review of Public Administration and Management Vol. 2 (2)

Chukwuemeka, E. (2012). Administration and Politics in Nigeria Past, Present and Issues, Lagos Vinez Publishers.

Chukwuma, O. (2008). Political Godfatherism in Nigeria: Benevolent and malevolent Factors. International Journal of Social and Policy Issues, $5(2): 86-93$.

Egwu, S. G (2005). Promoting Accountability and responsiveness in Government in Nigeria, In O. S. Abah (ed), Geographies of Citizenship in Nigeria, Zaria: Tamaza Publishing Co. Ltd.

Ezeani, E. O. (2003). "Public Accountability: A Conceptual Analysis" in E. O. Ezeani (Ed) Public Accountability in Nigeria: Perspective and Issues. Enugu: Academic Publishing Company.

Ezike, N. (2009). Repositioning Nigeria for future Politics, Journal of Policy and Development Studies 4(1) $23-30$.

Gambo, A (2007). Godfatherism and Electoral Politics in Nigeria, in Gambo, A (ed) Daily Tribune, January 14th.

Gambo, A. (2009). Godfatherism: Menace to Democracy, Journal of Social Studies 1(1) $25-33$.

Gideons, A. A. (2010). The Political Economy of Development in Africa, Makurdi: Destiny Ventures.

Goode, W. and Hatt. P. (1952). Methods in social Research, Singapore, McGraw Hill Book Company Inc.

Hyden, $G$ and Bratton, M (1991). Governance and the study of politics in Africa, Lynne Rienner Publishers.

Ibeogu, A. (2013). Public Enterprise Reform in Nigeria. Unpublished Article Paper, Ebonyi State University, Abakaliki.

Joseph, R (1991). Democracy and Prebendal Politics in Nigeria. The rise and fall of the second Republic, Ibadan: Spectrum Ltd.

Mbamara, C. I. C. (2004). Anxiety and Psychological factors in Godfatherism in Dukor, M (ed) Godfatherism in Nigeria's politics Lagos: Essence Library.

Ndubuisi, J. (2011). Politics in Nigeria: An appraisal, Enugu HRV Publishers.

Nkwede, J.O. (2014). Contemporary Political Analysis, Mimeograph, Department of Political Science, Ebonyi State University, Abakaliki. Department of Political Science, Ebonyi State University, Abakaliki.

Nnamani, C. (2004). The godfather phenomenon in Democratic Nigeria: Silicon or Real? International Journal of Philosophy: 1. 1

Odey, J. O. (2003). The Madness called Election. Snaap Press Ltd, Enugu, Nigeria.

Odey, J. O. (2005). Democracy and the Ripples of Executive Rascality. Snaap Press Ltd, Enugu, Nigeria.

Okoye, I. K. (2007). Political godfatherism, Electoral Politics and Governance in Nigeria, A paper presented at the $65^{\text {th }}$ Annual Conference of the MPSA held in Chicago, USA; April $12-15$.

Ome, E. M. (2004). Godfatherism and Executive Interface in our Justice System, in Dukor M (ed) Godfatherism in Nigeria's Politics, Lagos Essence Library.

Suenu, K. (2004). Political Violence, Issues and Evidence. UN Publications.

Tovoethin, P (2004). Godfatherism and Democratic Consolidation in Nigeria: Issues and Perspectives, in Dukor M. (ed). Godfatherism in Nigeria's Politics, Lagos: Essence Library.

United Nations Development Programme (1997). Re-conceptualizing Governance, Mimeograph.

World Bank (1991). Managing Development: The Governance Dimension, Discussion paper. 
